\title{
The Present Salience of Foreign Relations Law
}

\author{
Campbell McLachlan
}

\section{POPULISM, CONSTITUTIONAL LAW'S EXTERNAL FACE AND INTERNATIONAL LAW}

The choices that states make about how their internal constitutional systems relate to the world outside - the international - are not accidental. They reflect fundamental decisions about how open or closed the state is to international $\operatorname{law}^{1}$ and about the level at which governance decisions that affect societies are made. Despite this, the legal relationship between the domestic and the international is under-theorised. It has been characterised by a 'dichotomy [which] remains perhaps the least investigated of all the fundamental divisions in our political lives'.2

The fissure between the municipal and the international has been exposed to view - and exploited - by the contemporary rise of so-called 'populism' in many states. A key tenet of populism has been a form of exclusionary identity politics that, mobilising popular sovereignty, creates a division between 'the people' and the other, seen in Hobbesian terms as the enemy outside. ${ }^{3}$ Populism makes a claim to sociological legitimacy - that society should not be controlled by external forces - that leads to a turn against 'elites, supranational agreements, international judicial institutions or economic powers'. ${ }^{4}$ The result is a context in which international law is invoked, but in what

1 Helmut Philipp Aust, "The Democratic Challenge to Foreign Relations Law in Transatlantic Perspective', in Jacco Bomhoff, David Dyzenhaus and Thomas Poole (eds.), The DoubleFacing Constitution: Legal Externalities and the Reshaping of the Constitutional Order (Cambridge: Cambridge University Press, 2020), p. 345.

$=$ David Armitage, Foundations of Modern International Thought (Cambridge: Cambridge University Press, 2013), p. 10.

3 Jan-Werner Müller, What Is Populism? (London: Penguin Books, 2017), p. 3.

4 Paul Blokker, 'Populist Governments and International Law: A Reply to Heike Krieger' (2019) 30 EJIL 1009 at 1012. 
seems an increasingly antagonistic way, amounting often to a dialogue of the deaf. ${ }^{5}$

Despite the central importance of the external face of populism, surprisingly little attention has been paid to its legal significance, in comparison to its internal constitutional implications. ${ }^{6}$ The populist challenge to international law is particularly concerned with the boundary between the international and the domestic, in which national sovereignty - linked with the popular sovereignty of 'the people' - is invoked as the key concept. In legal terms, this means that the challenge presented by the external face of populism is not only about the way in which states interact on the plane of international law, in the discourse between states and in their engagement with and within international institutions. It is also, perhaps even principally, about the relation between the internal law and institutions of the state on the one hand and international law on the other. This is the domain of foreign relations law.

The result is that the renewed attention given to foreign relations law as a field of comparative study (and not merely an American Sonderweg) ${ }^{7}$ comes at a time when the legal doctrines are being tested and debated to an unprecedented extent in many states in ways that expose to view the underlying policies and principles served by the law in this area. Yet this is not only a linear story about the enlargement of executive power fuelled by popular mandate. In constitutional democracies, it also is an account of the ways in which the other organs of government, the legislature and the courts, articulate their own role.

The publication of the present collection of chapters - the fruit of a wellconceived symposium - therefore presents an opportunity to reflect on the manner in which foreign relations law mediates the relation between the domestic and the international legal realms at a time when this is a hotly contested boundary. This is not simply an exercise in comparing legal techniques. Rather, it invites consideration of a larger question: what is foreign relations law for?

It is possible to examine that question (as I have done elsewhere) as one of the perspective or conception of the function of foreign relations law with

5 James Crawford, 'The Current Political Discourse Concerning International Law' (2018) 81 Modern Law Review 1.

6 But see for important interventions: Philip Alston, 'The Populist Challenge to Human Rights' (2017) 9 Journal of Human Rights Practice 1; Heike Krieger, 'Populist Governments and International Law' (2019) 30 EJIL 971. For a more general survey: (2018) 49 Netherlands Yearbook of International Law 1-220.

7 Detlev F. Vagts, 'American International Law: A Sonderweg?', in Klaus Dicke et al. (eds.), Weltinnenrecht. Liber Amicorum Jost Delbrück (Berlin: Dunker \& Humblot, 2005), p. 835. 
which the field is approached. ${ }^{8}$ Seen in this way, both the scope of the field and the development of specific legal doctrines will be affected by whether foreign relations law is conceived as designed to maintain the exclusion of the international from the domestic realm; or alternatively to facilitate the reception of international law into the domestic sphere. It may bring the conduct of foreign relations within the domestic constitutional sphere or concern itself with the external conduct of diplomatic relations between states. Finally, it might be reconceived as a conflict of laws for public law, performing an allocative function on questions of jurisdiction and applicable law as they arise in the external exercise of public power. In this latter perspective, the field draws upon elements of public and private international law as well as constitutional law, even if (like private international law itself) it must always remain a part of the domestic law of each state.

This book shines a specific spotlight on the relationship between comparative foreign relations law and public international law. Amidst what Edward Swaine describes as 'the considerable, and understandable, excitement regarding the nascent field of comparative foreign relations law', ' it is worth pausing to ask what implications this might have for the development of international law itself. Is the turn to foreign relations law, as Anthea Roberts has suggested, 'an inherently conservative move'? ${ }^{10}$ After all, foreign relations law had been until recently hardly recognised as a field outside the United States. There it has taken a pronounced inward turn in the most recent generation of scholarship. Is it not more than coincidental that it should be exported as a comparative field at a time when the rise of populism, in the United States and elsewhere, increasingly resists the role of the international in the domestic polity?

What effect might the development of comparative foreign relations law as a field have on public international law itself? Helmut Aust and Thomas Kleinlein argue in their Introduction that it is precisely this by now established narrative of an "Ersatz international law" that should be challenged critically. ${ }^{11}$ But in order to do so, it is first necessary to consider that narrative. Section II will enquire whether, and if so how, an increased focus on foreign

8 Campbell McLachlan, 'Five Conceptions of the Function of Foreign Relations Law', in Curtis A. Bradley (ed.), The Oxford Handbook of Comparative Foreign Relations Law (Oxford: Oxford University Press, 2019), p. 21.

9 See the chapter by Edward T. Swaine, p. 46.

10 Anthea Roberts, Is International Law International? (New York: Oxford University Press, 2017), p. xx.

${ }^{11}$ See the chapter by Helmut Philipp Aust and Thomas Kleinlein, p. 1 at 8. 
relations law might itself undermine international law or create an 'Ersatz international law'.

The balance of this chapter considers two lines of response. Its central argument is that a renewed focus on the relation between international law and foreign relations law, which the present collection adopts, might in fact address such a critique.

Section III argues that, once the more extreme rhetoric of the populist critique of international law is stripped away, the debate exposes to view the importance of reconnecting the external and internal aspects of sovereignty. Populist leaders have adopted (and often appropriated for their own purposes) a much more deep-seated and genuine concern about the exercise of popular sovereignty vis-à-vis governance at the global level, which should not be dismissed. Brexit is emblematic of the reignition of a much larger and critically important debate about how 'the people' of a nation are to determine the manner in which they are to engage with the world. This is not a new issue, though it has been sharply re-exposed to view in the present era. In this debate, there is no necessary dissonance between international law - which retains as a peremptory norm the principle of self-determination ${ }^{12}$ - and the viability of a national constitution founded on representative democracy. On the contrary, it is the populist claim of an exclusive executive right to speak for the people in foreign relations that we should question.

Section IV then suggests a second important line of response. This is precisely that recognising the concerns of foreign relations law to be legal concerns (as opposed to the exercise of executive discretion in a zone of nonlaw) enables consideration of the interaction between the domestic constitution and international law as one concerned with the interaction of legal systems. In other words, it necessitates treating international law as law and the domain of foreign relations as not being purely political but as bounded by law. This is not about treating all exercises of foreign policy as constrained by law, still less as necessarily subject to domestic adjudication. Rather it requires us to take seriously the extent to which the executive foreign affairs function is bound by the international law obligations that it assumes on behalf of the state.

The diverse chapters collected in the present volume cast important light on a set of legal questions that arise out of a governance dilemma that many states now face with increasing urgency. It may well be impossible, as Dani Rodrik

12 International Law Commission, 'Draft Articles on Responsibility of States for Internationally Wrongful Acts, with commentaries' (2001) II(2) Yearbook of the International Law Commission 31 at 85 . 
has suggested, to have 'hyperglobalization, democracy and self-determination all at once'. ${ }^{33}$ But, even if we put aside 'hyperglobalisation', we must still find a way to reconcile popular engagement in the process of government at the national level with the necessity of international cooperation.

\section{AN ERSATZ INTERNATIONAL LAW?}

In order to challenge critically the idea that foreign relations law is a kind of Ersatz international law, as the editors of this volume invite us to do, it is first necessary to examine the nature of the charge. How might it be said that the emergence of foreign relations law, as a discipline on a global comparative scale, could adversely affect international law itself? Here experience in the United States, as the country in which foreign relations law as a distinct subject has the greatest prominence, may be instructive.

In an important contribution to the debate about the emergence of the field of comparative foreign relations law, Karen Knop identifies three anxieties about the effect of the creation of such a field on public international law itself in light of the American experience. ${ }^{14}$ In the first place, she notes that the study of foreign relations law has displaced international law in many American law schools, with the consequence that students are 'less likely to approach public international law as a legal system than instrumentally as one possible tool in the legal toolkit for solving transnational problems'. ${ }^{15}$ In the second place, she suggests that foreign relations law may end up taking dualism to its ultimate end. This 'deep dualism"16 discounts the legal quality of international law, such that 'the field of foreign relations law is structured as a divide between an internal realm in which law is the default and an external realm in which foreign relations is the default. ${ }^{17}$ In the third place, she identifies the risk that foreign relations law distorts the operation of international law: by inserting domestic concerns into the operation of international law; by encouraging non-compliance with international law at the national level, inserting boundaries derived from domestic constitutional law; or by opening the potential that domestic courts will simply misconstrue its obligations.

13 Dani Rodrik, The Globalization Paradox: Democracy and the Future of the World Economy (New York: W.W. Norton, 2012), p. 200.

14 Karen Knop, 'Foreign Relations Law: Comparison as Invention', in Curtis A. Bradley (ed.), The Oxford Handbook of Comparative Foreign Relations Law (Oxford: Oxford University Press, 2019), p. 3.

15 Knop, 'Comparison as Invention', p. 51.

16 Citing Alejandro Lorite Escorihuela, 'Cultural Relativism the American Way: The Nationalist School of International Law in the United States' (2005) 5 Global Jurist Frontiers 1.

17 Lorite Escorihuela, 'Cultural Relativism the American Way', 54. 
These concerns cannot be ignored, at least insofar as they are observable in the contemporary American context. Jens Ohlin argues in his book The Assault on International Law that the development of doctrines in US constitutional law that enhance executive discretion in foreign relations went handin-hand with scholarship that sought to undermine the determinate and binding character of international law. ${ }^{18}$

Recent experience also exposes the risk of blurring important lines of distinction between the operation of international and national law. Naz Modirzadeh describes how, after 9/11, international humanitarian law became 'at best a set of tools that could be operationalized alongside constitutional law, human rights law, and criminal law and procedure' in a form of 'folk international law'. ${ }^{19}$

Nor are these trends limited to the United States. John Finnis, arguing that the executive in the United Kingdom has no obligation to abide by the state's international law obligations, writes: 'International law remains, like it or not, a defective example of law. The criteria for its formation and identification remain opaque, controverted, and manipulable without redress' ${ }^{20}$

Chapters in this volume bear out some of the concerns that Knop identifies. Felix Lange shows how the insertion of the domestic constitutional law limitations of the United States into the negotiations shaped the outcome of the Paris Agreement on climate change at the international level, while providing no subsequent constraint on the executive decision to withdraw at the domestic level. ${ }^{21}$

Foreign relations law may also encourage the priority of constitutional law concerns over international law obligations. Angelo Golia recounts the refusal of the Italian Constitutional Court to give effect to the judgment of the International Court of Justice in the dispute between Germany and Italy on sovereign immunity for acts committed in World War II, in which it cited supreme principles of the constitution. ${ }^{22}$ As Curt Bradley observes, the

18 Jens David Ohlin, The Assault on International Law (New York: Oxford University Press, 2015). For an early important essay calling attention to this trend see: Peter J. Spiro, "The New Sovereigntists, American Exceptionalism and Its False Prophets' (2000) 79 Foreign Affairs 9.

19 Naz K. Modirzadeh, 'Folk International Law: 9/11 Lawyering and the Transformation of the Law of Armed Conflict to Human Rights Policy and Human Rights Law to War Governance' (2014) 5 Harvard National Security Journal 225 at 257.

20 John Finnis, 'Ministers, International Law, and the Rule of Law', Judicial Power Project, 2 November 2015, https://judicialpowerproject.org.uk/ministers-international-law-and-therule-of-law/, accessed 5 May 2020.

21 See the chapter by Felix Lange.

22 See the chapter by Angelo Jr Golia, discussing Decision No. 238/2014 of 22 October 2014 (Italian Constitutional Court); Jurisdictional Immunities of the State (Germany v. Italy: Greece intervening), Judgment, I.C.J. Reports 2012, p. 99. 
normative goals of foreign relations law will not always align with the normative goals of international law'.23

A closer embrace of international law at the national law level may also lead to its misapplication. Dire Tladi argues in his critique of the South African Constitutional Court judgment in the SADC Tribunal case that 'the problem with the Court is not only its conclusion but also its failure to engage with the methodology of international law' ${ }^{24}$

To these concerns, the rise of populism adds the prospect of an increasing outright withdrawal of states from the international legal system, facilitated by the exercise of an unbound executive discretion to withdraw within many domestic constitutions. ${ }^{25}$ This is a trend of which President Trump's announced withdrawals from the Paris Agreement and the Iran Nuclear Accord - both so recently and painstakingly negotiated - are emblematic. Yet the evidence of withdrawal, in particular from submission to international dispute settlement, is in fact much more widespread. ${ }^{26}$ Examples include the United Kingdom's withdrawal from the jurisdiction of the European Court of Justice under Brexit; the increasing challenge to the jurisdiction of the European Court of Human Rights; the threatened collective withdrawal of African states from the International Criminal Court; and the withdrawal of a number of key states from investment treaty arbitration. ${ }^{27}$ In each case, there is a striking similarity in one of the key strands in the arguments for withdrawal. Those objecting to the conferral of a power of adjudication over states upon international tribunals allege that this creates a democratic deficit. International judges, described as unaccountable international elites, are said to take decisions that constrain the power of peoples to exercise their popular sovereignty by determining the direction of their societies for themselves. They assert that this undermines the essence of the sovereignty of states.

International law has seemed curiously impotent in the face of these newly emboldened assertions of sovereignty, though I have argued elsewhere that international law does place checks on withdrawal, recognising that it is act that is not a matter of purely unilateral discretion, since of its nature it affects the interests of other states parties. ${ }^{28}$ The question that this phenomenon raises

23 See the chapter by Curtis A. Bradley, p. 345.

24 See the chapter by Dire Tladi, p. 229, discussing Law Society of South Africa and Others v. President of the Republic of South Africa and Others 2019 (3) BCLR 329 (CC).

25 See the chapter by Edward T. Swaine.

26 Campbell McLachlan, "The Assault on International Adjudication and the Limits of Withdrawal' (2019) 68 ICLQ 499, and the detailed references therein.

27 McLachlan, 'The Assault on International Adjudication', 507-10.

28 McLachlan, 'The Assault on International Adjudication', pt. IV. 
in the present context is whether a closer engagement between international law and foreign relations law is capable of nourishing new insights into the concept of sovereignty in its double-facing aspect: external and internal. ${ }^{29}$ Such a constructive engagement might furnish one possible set of responses to the critique outlined above. It is to this question that we must now turn.

\section{IS SOVEREIGNTY INDIVISIBLE?}

Modern international lawyers have a tendency to regard the sovereignty of states as something of an embarrassment - an inconvenient truth. In the last edition of Oppenheim that he edited in 1955, Hersch Lauterpacht concludes a passage on 'The problem of sovereignty in the twentieth century' with the optimistic suggestion that 'progress in International Law, the maintenance of international peace and, with it, of independent national States, are in the long run conditioned by a partial surrender of their sovereignty'.$^{\circ}$ Forty years later, Louis Henkin concluded in 1995 that 'for legal purposes at least, we might do well to relegate the term sovereignty to the shelf of history as a relic from an earlier era'. ${ }^{31}$ James Crawford insists in 2005 that the term sovereignty as a legal term can only mean 'the totality of powers that States may have under international law. By contrast, as a political term its connotations are those of untrammelled authority and power and it is in such discourse that the term can be problematic'. ${ }^{32}$

The view of international lawyers that sovereignty is unhelpful in legal terms stands in stark contrast to its persistence. This is not only in international political discourse, in which, for instance, Brexit was cast as 'a fight for the very sovereignty of our nation'; 33 and President Trump repeatedly invoked at the rostrum of the UN General Assembly the notion that: "The future does not belong to globalists. The future belongs to patriots. The future belongs to sovereign and independent nations ....34 It also finds its way into international legal discourse. The Beijing Declaration adopted by the first South-South Human Rights Forum in 2017 resolves that: 'The international community's

29 The author is indebted to David Dyzenhaus for the term 'the double-facing constitution'. See Bomhoff, Dyzenhaus and Poole (eds.), The Double-Facing Constitution.

30 Lassa Oppenheim and Hersch Lauterpacht (eds.), International Law: A Treatise, 8th ed. (London: Longmans, Green \& Co, 1955), pp. 122-4 at para. 70.

${ }^{11}$ Louis Henkin, International Law: Politics and Values (Dordrecht: Martinus Nijhoff Publishers, 1995), p. 10.

32 James Crawford, The Creation of States in International Law, and ed. (Oxford: Oxford University Press, 2006), p. 33.

33 The Spectator, 15 December 2018.

34 Statement of President Trump to the UNGA, 24 September 2019, UN Doc. A/74/PV.3, p. 11. 
concern for human rights matters should always follow international law and the universally recognized basic norms governing international relations, of which the key is to respect national sovereignty. ${ }^{35}$ So too the proposal for collective withdrawal from the International Criminal Court considered by an Open-ended Ministerial Committee of the African Union in January 2017 , invoked the need to '[p]reserve the dignity, sovereignty and integrity of Member States. ${ }^{36}$

The comparative failure of international lawyers to engage with the concept of sovereignty, in both its internal and external aspects, may, as John Jackson presciently warned in 2003 , actually promote the persistence of sovereignty fictions such as 'the notion that absolute power is concentrated at the head of a nation-state'. Jackson argued that an attempt to bury the concepts of sovereignty 'without adequate replacements could lead to a situation in which pure power prevails: that, in turn, could foster chaos, misunderstanding, and conflict, like Hobbes' state of nature, where life is "nasty, brutish, and short". ${ }^{37}$

Jackson was writing at a time of great expansion in the ambition of international institutions and was driven by a perception of the entirely new set of pressures that this was creating for 'nation-state governments trying to deliver the fruits of their important achievements to their constituents' ${ }^{38}$ In other words, he was concerned about the effect of exercises of sovereignty on the plane of international law on the maintenance of popular sovereignty in national constitutions. Seen in this light, the rise of populism has simply exposed to view what Blokker calls a 'deeper, intrinsic tension in the postwar international legal order between democratic self-government on the one hand, and a universalistically understood international regime, on the other'. 39

This is a serious concern that lies at the heart of several of the chapters in this volume. It is not to be dismissed as mere populist rhetoric. Aust and Kleinlein suggest in their Introduction that 'Sovereignty often serves as a placeholder for constitutional values, in particular domestic democratic selfdetermination'. $4^{\circ}$ As Anna Petrig puts it, discussing the Swiss constitutional debate about the Migration Pact: "To shrug off the call for "hard

\footnotetext{
Beijing Declaration, 8 December 2017, p. 8.

African Union, 'Withdrawal Strategy Document - Draft 2', 12 January 2017.

37 John H. Jackson, 'Sovereignty-Modern: A New Approach to an Outdated Concept' (2003) 97 AJIL 782 at 794 .

$3^{8}$ Jackson, 'Sovereignty-Modern', 797.

39 Blokker, 'A Reply to Heike Krieger', 1014.

$4 \circ$ See the introductory chapter by Helmut Philipp Aust and Thomas Kleinlein, p. 17.
} 
participation", which took shape in the context of the Migration Pact, as a purely populist manoeuvre would not do the matter justice'. ${ }^{41}$

International law resists conflating the question of the sovereignty of a state on the international plane with the 'constitutional lawyer's question of supreme competence within a particular State'..$^{42}$ At the same time, there is a strong strain in foreign relations law, which finds its philosophical origins in John Locke's idea of the 'federative power' that would leave the conduct of foreign relations in the hands of the executive. ${ }^{43}$ On the face of it, these two claims seem to contradict rather directly the notion, now so widely exploited by the populist leaders, of the importance of a direct link between 'the people' and the exercise of independent sovereignty on the international plane, for which the Brexit referendum is emblematic.

Yet a closer focus on the relation between the international and the domestic dimensions of sovereignty and on the contribution of, respectively, international law and constitutional law might assist our understanding of this relationship. In his highly original monograph Sovereignty published in 1933, Hermann Heller argued for the indivisibility of sovereignty. He wrote:

If a state is sovereign, it is the universal decision-making unit in its territory; the existentiality of the decision-making unit prohibits splitting sovereignty into the sovereignty of a state law and a separate international law sovereignty. ... The highest independent decision-making power is always the mark of one and not two facts. ${ }^{44}$

In his view, it was essential to liberate the idea of the sovereign person from the 'bloodlessness' of a 'conceptual phantom labelled the state'. ${ }^{5}$ He located sovereignty in the people as the body politic, but, distancing himself from Carl Schmitt's conception of a 'voluntaristic dictatorship' he insisted that the people may only govern through the appointment of representatives 'juristically dependant magistrates' that represent the common will. ${ }^{46}$

Several of the chapters in this volume examine the development of mechanisms that seek to enhance and protect democratic involvement in the decisions of states on the international plane, which comparative research

\section{English tanslation of the}

(Oxford: Oxford University Press, 2019), p. 140.

45 Heller, Sovereignty, pp. 104, 106.

$4^{6}$ Heller, Sovereignty, p. 108. 
shows is a global trend. ${ }^{47}$ Both Ajla Škrbić and Stanislaw Biernat consider the case for an enlarged parliamentary role in controlling the executive's use of the foreign affairs power. ${ }^{4}$ Niki Aloupi shows how the Conseil Constitutionnel in France mediates the effect of international commitments upon national sovereignty, through its decisions on whether a constitutional amendment is required as a condition for the ratification of a treaty. ${ }^{49}$

Veronika Fikfak, who considers the development of British parliamentary practice on the use of force against the background of a much broader comparative trend, argues that this development is not only about the accountability of the executive to Parliament. Examining the parliamentary debates, she suggests that, in the process, a direct link has been forged between the questions of the lawful use of force at international law and Parliament's responsibility at the national level to decide to authorise the use of force. ${ }^{50}$ In the process, the international law issues become domesticated.

These trends, important though they are, still fall short of Heller's conception of indivisible sovereignty through the exercise of the ultimate power of decision on foreign affairs by the elected representatives of the people. Nevertheless, recent experience in the United Kingdom concerning the decision to withdraw from the European Union gives support to this idea. Brexit concerned an exercise of the foreign affairs power: the decision to withdraw from a Treaty (and the whole complex of international arrangements that flow from it). The process in the United Kingdom began with that most un-British of constitutional devices: a resort to direct popular democracy through the medium of a referendum. Immediately thereafter the executive (vociferously backed by elements in the Press) attempted to treat this as a mandate that could be executed by a straightforward exercise of its foreign affairs prerogative. $^{51}$

In two landmark cases, the Supreme Court demurred, decisively finding in favour of Parliamentary sovereignty, that is: the principle that the sovereignty of the people may only be exercised through their representatives (however chaotic the results may be) and that this principle applies as much to foreign

47 Pierre-Hugues Verdier and Mila Versteeg, 'International Law in National Legal Systems: An Empirical Investigation' (2015) 109 AJIL 514; Pierre-Hugues Verdier and Mila Versteeg, 'Separation of Powers, Treaty-Making, and Treaty Withdrawal: A Global Survey', in Curtis A. Bradley (ed.), The Oxford Handbook of Comparative Foreign Relations Law (Oxford: Oxford University Press, 2019), p. 135.

$4^{8}$ See the chapters by Ajla Škrbić and Stanislaw Biernat respectively.

49 See the chapter by Niki Aloupi.

50 See the chapter by Veronika Fikfak.

${ }^{51}$ For a detailed account of the background see: Campbell McLachlan, "The Foreign Relations Power in the Supreme Court' (2018) 134 Law Quarterly Review 380. 
relations as it does in other spheres. The first case directly concerned the decision to notify withdrawal. The second concerned a decision to prorogue Parliament while withdrawal negotiations were ongoing.

In Miller (No. 1), ${ }^{52}$ the Court rested its decision on the ground that the decision of the executive to withdraw would necessarily change the law applicable within the United Kingdom, something that only Parliament was competent to do. In this way, the Court could present the outcome as upholding the 'dualist system' that separated the international from the national and in turn the executive foreign affairs function from the legislative function of Parliament. It was only because the nature of withdrawal from EU law necessarily transgressed that line that the court had to intervene, since the dualist system is a necessary corollary of Parliamentary sovereignty ... it exists to protect Parliament not ministers. ${ }^{53}$

In Miller (No. 2), ${ }^{54}$ however, the issue could not be analysed as an application of dualism in law-making. The Court recognised that what was really at stake in the prorogation of Parliament was not merely an internal question of the distribution of powers between the executive and Parliament, but also one that went to the heart of Parliament's ability to scrutinise the executive conduct of foreign affairs. The constitutional significance of that power of supervision was one that Dicey early identified. He accepted that it is not Parliament but the Ministry, who direct the diplomacy of the nation'. ${ }^{55}$ At the same time, Ministers were constantly accountable to the House of Commons for the exercise of that power. In this way, he thought "The prerogatives of the Crown have become the privileges of the people. ${ }^{56}$ For the Supreme Court, the principle of 'Parliamentary accountability' is 'no less fundamental to our constitution than Parliamentary sovereignty' since: 'By these means, the policies of the executive are subjected to consideration by the representatives of the electorate, the executive is required to report, explain and defend its actions, and citizens are protected from the arbitrary exercise of executive power'. 57

Does this mean that the sovereignty of Parliament now includes the sovereign power of decision on all matters of foreign affairs? The answer is still

$5^{2} R$ (Miller) v. Secretary of State for Exiting the European Union [2017] UKSC 5, [2018] AC 61.

$53 R$ (Miller) v. Secretary of State for Exiting the European Union [2017] UKSC 5, [2018] AC 61 at $[57]$.

54 R (Miller) v. Prime Minister [2019] UKSC 41, [2020] AC 373.

55 Albert Venn Dicey, Introduction to the Study of the Law of the Constitution, 2nd ed. (London: Macmillan \& Co., 1886), p. 394.

56 Dicey, The Law of the Constitution, p. 396.

57 R (Miller) v. Prime Minister [2019] UKSC 41, [2020] AC 373, 406 at [46]. 
probably not: the gradual increase in Parliamentary supervision of treatymaking and the growth of a convention with regard to prior consultation on the war power do not amount to a full assumption of power. Nor would this be consistent with the important value of the separation of powers in constitutional government that requires a balance to be maintained between the three organs of government. Nevertheless, the 'crisis' test that Heller invites us to apply has demonstrated, at least in this one contemporary example, the need in the last resort to find a single holder of sovereign power within the state. Within a democratic state, that holder can only be the constitutionally appointed representatives of the people.

How, then, can this domestic constitutional law point be connected with international law in a way that supports the idea of an indivisible sovereignty? The answer lies in one of the most central organising principles of the postWar system of international law: the principle of self-determination.

The principle is enshrined in the United Nations Charter as one of the principal purposes of the Organisation, being 'respect for the principle of equal rights and the self-determination of peoples'. ${ }^{5}$ It has been subsequently developed through law-making resolutions of the General Assembly on Colonial Peoples ${ }^{59}$ and on Friendly Relations ${ }^{60}$ and as the first human right in the International Covenants. ${ }^{61}$ In the latter, in common article 1, it finds its expression in the following way:

(1) All peoples have the right to self-determination; by virtue of that right they freely determine their political status and freely pursue their economic, social and cultural development.

(2) All peoples may, for their own ends, freely dispose of their natural wealth and resources without prejudice to any obligations arising out of international economic co-operation, based on the principle of mutual benefit, and international law. In no case may a people be deprived of its own means of subsistence.

$5^{8}$ Charter of the United Nations, San Francisco, 26 June 1945, entered into force 24 October 1945, 1 UNTS 16, Art. $1(2)$.

59 UNGA, 'Declaration on the Granting of Independence to Colonial Countries and Peoples', UNGA Res. 1514 (XV), UN Doc. A/RES/1514 (XV), 14 December 1960.

6o UNGA, 'Declaration on Principles of International Law concerning Friendly Relations and Co-operation among States in accordance with the Charter of the United Nations', UNGA Res. 2625 (XXV), UN Doc. A/RES/2625 (XXV), 24 October 1970 ('Friendly Relations Declaration').

61 International Covenant on Economic, Social and Cultural Rights, New York City, 16 December 1966, entered into force 3 January 1976, 993 UNTS 3, Art. 1; International Covenant on Civil and Political Rights, New York City, 16 December 1966, entered into force 23 March 1976, 999 UNTS 171, Art. 1. 
(3) The States Parties to the present Convention, including those having responsibility for the administration of Non-Self-Governing and Trust Territories, shall promote the realization of the right to selfdetermination and shall respect that right, in conformity with the provisions of the Charter of the United Nations.

In turn it has been developed and implemented through the practice of the United Nations. No single principle has more profoundly transformed the international legal system. ${ }^{62}$ Respect for it as 'one of the essential principles of contemporary international law ${ }^{63}$ is an obligation erga omnes, which all states have a legal interest in protecting. ${ }^{64}$

The point here is that the self-determination creates an explicit link between international law and the 'people' who are and remain the holders of the right. ${ }^{6}$ Self-determination as a legal principle has both driven the emergence of new States and limited the validity of attempts to create new states that do not meet its criteria. But for present purposes, its significance lies in its enduring application internally within the framework of an existing state. ${ }^{66}$ In this way, international law supports the essential connection between the internal and the international role of self-determination: between the people and their right to determine their political organisation. So, renewed attention to the connection between international law and foreign relations law may shed new light on the meaning of popular sovereignty and its relation to the right to self-determination.

This point is important because the international law principle of selfdetermination is no populist charter, licensing the will of the majority to the exclusion of the human rights of individuals. Its expression as a matter of customary international law in the Friendly Relations Declaration includes the provision that: 'Every State has the duty to promote through joint and separate action universal respect for and observance of human rights and fundamental freedoms in accordance with the Charter' ${ }^{67}$ The same principle adds, in its savings clause, that the consequence of due observance of the principle of equal

62 Crawford, The Creation of States, Ch. 3; Marcelo Kohen, 'Self-Determination', in Jorge Viñuales (ed.), The UN Friendly Relations Declaration at 50 (Cambridge: Cambridge University Press, 2020), Ch. 7.

63 East Timor (Portugal v. Australia), Judgment, I.C.J. Reports 1995, p. 90, para. 29.

${ }^{6}$ Legal Consequences of the Separation of the Chagos Archipelago from Mauritius in 1965 , Advisory Opinion, 25 February 2019, para. 180.

${ }_{65}$ For a recent exploration of this idea in the context of election interference see: Jens David Ohlin, Election Interference (Cambridge: Cambridge University Press, 2020), Ch. 4 'The Promise of Self-Determination'.

66 Reference re Secession of Quebec [1998] 2 SCR 217, 282 at [126].

67 Friendly Relations Declaration, principle 5, paragraph 3. 
rights and self-determination of peoples is that the State is 'thus possessed of a government representing the whole people belonging to the territory without distinction as to race, creed or colour' ${ }^{68}$ The insertion of the right in the international human rights covenants has the same consequence that it is to be read together with all of the other rights protected thereunder.

There is a second respect in which a focus on the relationship between international law and foreign relations law may also prove productive. That lies in treating seriously its starting premise: that international law constitutes a distinct legal system, and that part of the function that foreign relations law may perform within a domestic legal system is to provide rules of reception, or, put more broadly, rules that manage the interaction between legal systems by determining which legal system has jurisdiction over which issues and what law applies. It is to this aspect that we must now turn.

\section{INTERNATIONAL LAW AS LAW}

In their Introduction, Aust and Kleinlein reject the idea that international law or foreign relations law are 'hybrid in nature'. They seek to uphold 'the rather traditional view that international law is indeed international and that foreign relations law is part of a given domestic legal system'. Nevertheless, they argue that 'foreign relations law encapsulates the rules of domestic law about the reception of international law' and that 'upholding the traditional criteria ... does not preclude investigating the hybrid zone that is created by the encounters of public international law and foreign relations law'. ${ }^{69}$

This approach may provide a potential way of pursuing Knop's suggestion that '[o]ne way forward may lie in noticing and questioning the strong law/ politics distinction at play in both foreign relations law and the international law that it threatens to displace, discount, or distort'. ${ }^{70}$ In other words, it may answer the distinction - implicit or explicit in some contemporary foreign relations law scholarship - between a relatively positivist approach to binding law at the domestic constitutional level and the assumption that, beyond the state, the international arena can be characterised only by foreign relations and not by binding law.

The partially revised American Law Institute Restatement (Fourth) Foreign Relations Law 2018 makes the point that, because a restatement of foreign relations law 'deals with two distinct legal systems, namely domestic law

69 See the chapter by Helmut Philipp Aust and Thomas Kleinlein, p. 12.

70 Knop, ‘Comparison as Invention', p. 58. 
bearing on foreign relations and relevant portions of international law, it must address both' ${ }^{71}$

How might a renewed focus on treating the interface between international law and domestic constitutional law as one of the interaction between legal systems actually make a difference? In the first place, it might challenge the utility of conventional ways of analysing the reception of international law in domestic legal systems as one determined by the distinction between dualist and monist systems. Recent comparative research has shown that this traditional distinction does not correctly explain the actual rules of recognition applicable in states that are traditionally regarded as being 'monist' or 'dualist'. ${ }^{22}$ The true position is much less black and white.

'Monist' states must still maintain procedures for treaty review and ratification to ensure legislative control over the making of laws that are to be applicable internally within the state. 'Dualist' states, even if they maintain strict rules of separation between treaty obligations and domestic law may still accept that customary international law is 'part of the law of the land'. ${ }^{73}$ When they do so, this is not because international law is referred to in the interpretation of a norm of municipal law. Rather it is because international law is applicable to the determination of the issue within the municipal legal system. It is applicable because a rule of recognition of municipal law so provides, and therefore subject to the terms on which municipal law admits the international law rule. But it is nevertheless applicable as law. ${ }^{74}$

A consideration of the internal effect of the international legal obligations assumed by states might also lead us to question deep dualism in another respect. It would challenge another mistaken dualist proposition that international law obligations sound only on the international plane and produce no domestic effects. It would do so by demonstrating that the essential corollary of the allocation to the executive of the power to conduct foreign affairs and to enter into treaties is that the executive assumes a concomitant obligation to comply with the international law obligations that it has assumed. Such a requirement (which is supported in the case of the United Kingdom by several centuries of practice) ensures that the state abides by the international

${ }^{71}$ American Law Institute, Restatement (Fourth) of the Foreign Relations Law of the United States (2018), Introduction.

$7^{2}$ Verdier and Versteeg, 'International Law in National Legal Systems', 514.

73 William Blackstone, Commentaries on the Laws of England, gth ed. reprint (Oxford: Strahan, Cadell and Prince, 1783) Bk IV, p. 67. See the Indian Supreme Court authorities cited in the chapter by Prabhakar Singh.

74 The point is developed fully in Campbell McLachlan, Foreign Relations Law (Cambridge: Cambridge University Press, 2014), Ch. 3. 
law obligations that it has assumed through the persons that contract on its behalf and represent it in foreign relations. ${ }^{75}$

The result of treating foreign relations law as concerned with the interaction of the different legal systems that are in play in questions of foreign relations 'admits of a larger variety of relevant bodies of law. It also has the potential to develop a more complex account of dualism'. ${ }^{76}$ In rejecting a 'fixed law/ politics opposition' it would subject foreign relations questions to the principle of legality, not conceived narrowly as the municipal law of any particular state, but rather as determining the issue according to the applicable law, whether that be municipal law or international law.

A further benefit of such a focus is that it may provide a better means of doing comparative foreign relations law on a global basis. Michael Riegner, in his chapter for this volume, highlights the contingency of the set of choices for foreign relations law created by the Western constitutional tradition. ${ }^{77} \mathrm{He}$ points out that this tradition assumes the pre-existence of the state and then poses the foreign relations law question as a set of choices about the relation of the state to international law at the interface. He argues that the distinction between international and national is applied rigidly to the political sphere but not to the economic sphere'. ${ }^{7}$

By contrast, in the colonised Third World, 'foreign relations did not begin as inter-state relations but as dealings between chartered trading companies like the East India Company and local rulers. The experience of statehood was also quite different: for many postcolonial states, the international preceded the national: peripheral statehood was produced and defined by international law during decolonization'.79 A search for models of foreign relations law in the Global South would, as the Latin American example that he discusses illustrates, open up the possibility of transformational constitutionalism, a model of regional integration that emphasises social not economic rights, which remain much more closely subject to national control. ${ }^{80} \mathrm{We}$ might note in this regard how closely the formulation of the right to self-determination in Article 1 of the International Covenants links the right of peoples to determine

75 Campbell McLachlan, "The Double-Facing Foreign Relations Function of the Executive and Its Self-Enforcing Obligation to Comply with International Law' in Bomhoff, Dyzenhaus and Poole (eds.), The Double-Facing Constitution, Ch. 13.

76 Knop, 'Comparison as Invention', p. 60.

77 See the chapter by Michael Riegner, pp. 6o et seqq.

$7^{8}$ See the chapter by Riegner, pp. 65-66.

79 See the chapter by Riegner, p. 69.

8o See the chapter by Riegner, p. 74 . 
political status (paragraph 1) to their right to control economic resources (paragraph 2).

\section{CONCLUSION}

If comparative foreign relations law proves itself really capable of embracing different perspectives as to the relation between a national constitution and international law that treats both as law, it might rise above a mere comparison of differences. It might then dispel the concern that, as a discipline, it may cannibalise the study of international law, creating in the process an Ersatz or 'folk' international law. In doing so it may shed new positive light on a compelling issue of our age on which foreign relations law sits, whether as bridge or boundary, namely: how to redefine the relation between the nation state and the international realm in ways that give real meaning to both the right of peoples to self-determination and the community interest shared by all humanity to secure our common future. 